\title{
Self-directed learning research paper is good at excavating students' study potentialities
}

\author{
Li Guilin \\ Department of Physiology \\ School of Basic Medical Sciences of Nanchang University \\ Nanchang 330006, China
}

\author{
Liang Shangdong* \\ Department of Physiology \\ School of Basic Medical Sciences of Nanchang University \\ Nanchang 330006, China \\ Corresponding author: liangsd@hotmail.com
}

\begin{abstract}
In order to excavate the potential of students' autonomous learning and to cultivate the students' ability of autonomous learning, we adopt the teaching method that allows undergraduate students to study independently in scientific research papers. In medical theory teaching class, active learning is one of the important issues in the implementation of quality education. Our teaching reform method is the introduction of Chinese scientific research papers in the physiological teaching, and students collect relevant knowledge from the network and make multimedia courseware, then they explain and answer relevant questions in class. We find that the reform of the teaching method can fully tap the potential of students' autonomous learning, and actively cultivate the ability of students' autonomous learning. Each teacher in the teaching work should pay attention to the cultivation of students' autonomous learning ability, so that medical students in the clinical medical work in the face of rapidly changing complex conditions have better response capabilities.
\end{abstract}

Keywords-self-directed learning; research papers; learning potentialities; reform in education

\section{INTRODUCTION}

In today's world of internationalization, knowledge is no longer the sole criterion for measuring talent, while cultivation of the abilities becomes more important. Autonomous learning is an important subject of education research. The cultivation of students' autonomous learning abilities is not only good for students to improve their academic performance, but also good for them to adhere to lifelong learning. How to realize the active development and autonomous learning of medical students is an important project of how to implement quality education in medical theory teaching. To achieve this goal, teachers should change the traditional education idea, realize the students as the main body, fully mobilize students' enthusiasm and initiative in medical knowledge learning, and actively deal with the relation between the teacher's guidance and students' master. Teachers also must change teaching methods, fully tape the potential of students' autonomous learning, actively cultivate students' abilities of active learning, in order to achieve the purpose of medical students learning by themselves and overall qualification promotion of medicals students.

\section{METHODS}

In order to promote students' autonomous learning abilities training, our teaching teams introduce Chinese research papers in physiology teaching of freshman in Nanchang University medical college. As the Nanchang University is the place of the 211 universities, the students are uneven, in order to take into account the purpose of all the students' participation, we choose Chinese research papers to adopt teaching reform in the course in freshman. According to our teaching team members to carry out the National Natural Science Foundation research work of the subject, we choose the professor Liu's ${ }^{[1]}$ elctrophysiology of myocardial and professor Wang's ${ }^{[2]}$ anti thrombotic effects of acetylcholine in vascular endothelial cells as the research papers.

More than three weeks before reform of teaching practice, research papers above and 2 review articles related to the papers were sent to clinical students. Give the following questions: (1) What are the experimental method used in this study? What is the level of physiological research carried out in the experiment? (2) What help do you know about the physiology of your knowledge after the results of the study? (3) To describe briefly, what are the research purposes, research methods, and innovative results of this paper? (4) What has been found through the study of this paper about the new drug targets? According to the experimental results, what is the possible mechanism? (5) Through the research of this paper, what is helpful for the clinical treatment of diseases? why? Students in various classes are divided into several study group, they study the research papers on extracurricular activities, and collect relevant medical knowledge and make multimedia courseware from the network. In the class discussion, each group recommend 1-3 students to explain their learning ideas of research papers that they own group study, other students can put forward questions at any time to make the students or other students in the cooperative group to explain the problems. If there is a problem that the teams can't answer, other students in the class are also available to answer. If there are some questions that the whole class students can't answer, finally the teachers guide them to find answers.

\section{RESULTS}


Through the teaching reform practice of training independent learning abilities of the first grade students for three years, we have gained the following experience:

\section{A. To enhance the practical process of the students' team spirits}

The ancient Chinese educator Yan Zhitui has ever said "Science alone without friends is solitude and smell." That is to say to each other to be able to get informed opinions ${ }^{[3,4]}$. The team work carrying out scientific research papers can help develop the students' team spirits, which is also teaching organization forms of active education. Making use of group cooperative learning can achieve the purpose of complementary advantages of students, which is conducive to enhancing students' awareness of inquiry and promoting the development of students' communicative competence and solving problems abilities, which improve the efficiency of students in a certain period ${ }^{[5]}$. In our teaching reform practice, after class each group collects relevant medical knowledge in internet according to the research paper and makes multimedia courseware of class discussion. In addition, the group members make a supplementary statement to other students in class discussion. Many answers to the questions beyond the textbook are in place, which highlights the strength of team cooperation.

\section{B. To fully tap the students' learning potential}

Every student possesses enormous potentialities of developing spirits of innovation and inquiry abilities. Suhomlinski, the former Soviet Union educator, claimed that the skills and arts of teaching and educating lie in exploiting every child's power and possibilities ${ }^{[6]}$. While self-directed learning research paper, students search materials on Internet and make media coursewares which are very animated, such as, a student group's PPT aiming at the influence to myocardial electric rational caused by earl sodium channel current increasing. The media courseware of research paper tansform the forms in papers into tendency charts and introduce the results of relevant thesis to help students understand studied results. In the meantime, they also explain that congenital LQTS is due to gene mutation of regulating ventricular repolarization muscle cell membrane ion channel ${ }^{[1]}$.Students query and then clear-up doubts by automic learning. By automic learning, students take positive, conscious, automic ways to acquire knowledge use knowledge and solve problems. Scientific research has proved the enormous potentialities of human brain. Our teaching reform indicated that the adaptability of junior grade medical students is very big and teachers should take proper means to fully exploit their study potentialities.

\section{The best way to actively cultivate students' innovative thinking}

Germany educator has ever said: A good teacher teaches people to find truth, while a bad teacher delivers truth ${ }^{[7]}$. Innovative thinking is the thought that is not constrained by old notices but they would like to pursuit innovation and creation. It is the emphasis to cultivate students' creative thoughts while asking is a useful and effective means to develop innovative thinking. Conventional theory teaching puts too much emphasises on receiving and understanding knowledge, neglecting cultivating exploration and discovery abilities of students, which hinders the development of innovative thinking. In practice, the process of congnitive processing, the actiive learning of students becomes passive acceptance and memory process. Because the study aim itself is an innovative point, students should constantly analyse materials from Internet and then sum up it. What's more, students had better continuously think in the process of analysing and exploring research paper and judge it true or false. This teaching reform make students think actively and autonomously in teaching process and it arouse their innovative consciousness and well cultivate creative thoughts.

\section{The important measures to effectively leader conscious learning of students}

Diesterweg, German educator, has pointed it out clearly in the teachers' rules: the art of education is not the ability of teaching, but encouraging, awakening, inspiring ${ }^{[8]}$. Most medicos have abundant thirst of knowledge, arousing their enthusiasm for study accurately will make them take an active part in activities of study. During the autonomic learning about research paper, students will compare the achievements that based on their independent learning and thinking with part of teachers' explaining about the complex issues, and make impacts between their own thinking of wisdom and the opinions of predecessors and others. They learn the knowledge of Medical Science in collisions, and improve themselves, discover themselves further, and make their own learning progresses efficient and interesting. Through preparing actively for class, the students can give suitable answers and make decent debates for the contents explained in discussion class about research papers, the questions other students have asked and issues related among students. Funny answers the students give out to some questions always make the class burst into laughter. Because students become the main part of study, their subjective initiatives are full used. So, such learning progress is propitious for students to gain overall improvement during their autonomous learning which they are interested in, and it's also an important measure to train medicos to do active inquiry, team work and innovation.

\section{E. The proper ways to show students' bardian specialty strenuously}

Howard, a psychologist in Harvard University, came up with multi intelligence theory in 1980s, which says that human intelligence is polybasic. Everyone has his own intelligence spectrum, which will be shown out by all kinds of activities, each of the intellectual spectrum is different from others', each kind of intelligence is very important, can be developed and cultivated $^{[9]}$. Therefore, on the basis of people oriented educational view, we must pay attention to different characteristics and proficiencies of different students to make every student develop. The content of courses about research papers that we give out is exoteric, there is no agreed answer, so students can answer the questions by the knowledge they know and get on the internet. Although the contents that every student gives out may be not perfect, everyone have the chance to express his own view, and all the contents will be probably complete when integrated. Through this teaching 
process, students get the chance to show their individual talents develop their individual strengths and make up their individual weaknesses, they learn from others' strong points and close the gap, at the same time they can show their advantage and characteristics. Because the structures basics of knowledge of every students may be different from others, when help students with the methods of macro level, teachers encourage students to explore and perfect the methods of macro level that fit them more, and communicate with each other to learn from others' strong points and close the gap at the microscopic level. Thus, such method of autonomous learning which makes research papers as content of courses can show students' potential personality of the specialty fully, so that their selfconfidence to study seriously is built up and lead to their harder study.

\section{CONCLUSIONS}

All in all, it's important for students to learn medical knowledge during their university, but what's more important is to learn to think, develop the ability of independent learning and innovation research, and enhance the ability for independent study. The more important thing that teachers should do is to lead the students to find out the solutions of problems, just like give them fishing rod rather than fish. What students need to do to adapt the future society is to study in their whole lives and enhance themselves continually. And lifelong learning requires that each person has independent learning ability, independent of the teacher and the classroom. Health related, life entrusted. Medical students will be medical workers in the future, which will assume a scared mission of healing the wounded and rescuing the dying. Because of this, teachers should care more about the education of students' ability to study by themselves in our teaching jobs to make students have a better coping capacity when they face the rapidly evolving state of illness in their clinical wore after they graduated from school.

\section{REFERENCES}

[1] H.W., Wang, W., Zhao, Z., Yang, C.Z., Li, Y.M., Liu, "Effect of early sodium channel current increase on the electrophysiological properties of cardiac myocytes". Journal of Shanghai Jiao tong University (Medical science), vol. 26, pp. 1011-1014, September 2006.

[2] D.M., Chen, S.F., Mu, H., Wang, "Antithrombosis through activating endothelial target for acetylcholine and its molecular mechanism". Chinese Pharmacological Bulletin, vol. 18, pp. 527-531, May 2002.

[3] L.Q., Wang, "In addition to this solution YanShiJiaXun" [M]. Beijing: Zhonghua Book Company, 1993.

[4] T.L., Zhuang, "On the viewpoint of Zhitui Yan”. Journal of university of Jinan, vol. 17, pp. 67-70, March 2007.

[5] F., Wang, H.B., Zhou, Y.S., Zhao, "Application and thinking of group cooperative learning in practice lesson of epidemiology", Chin J Med Edu Res, vol. 13, pp. 338-340, April 2014.

[6] H., Fan, "Study on Application of drama in English teaching and learning", Teaching and management, vol. 9, pp. 136-138, 2013.

[7] C.H., Zhou, L., Zhang, "Cultivating students' autonomous learning ability is an effective way to excavate students' learning potential", Journal of Liaoning Educational Institute, vol. 15, pp. 67-69, June 1998.

[8] Y.L., Ren, "The significance of cultivating students'autonomous learning medical ability", Social sciences journal of univesities in Shanxi, vol. 25, pp. 104-105, October 2013.

[9] B.S., Liu, "To provide greater space for development of students personality. - Case: design and make a mechanical model", Journal of Physics Teaching, vol. 31, pp. 1-3,6, July 2013. 